\title{
Correction to: Development of Guanfacine Extended-Release Dosing Strategies in Children and Adolescents with ADHD Using a Physiologically Based Pharmacokinetic Model to Predict Drug- Drug Interactions with Moderate CYP3A4 Inhibitors or Inducers
}

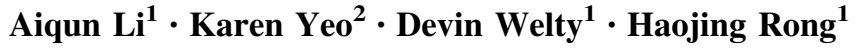

Published online: 28 December 2017

(c) The Author(s) 2017. This article is an open access publication

\section{Correction to: Pediatr Drugs}

https://doi.org/10.1007/s40272-017-0270-0

Attribution-NonCommercial 4.0 International License (http://creativecommons.org/licenses/by-nc/4.0/), which permits any noncommercial use, duplication, adaptation,

The article "Development of Guanfacine Extended-Release Dosing Strategies in Children and Adolescents with ADHD Using a Physiologically Based Pharmacokinetic Model to Predict Drug-Drug Interactions with Moderate CYP3A4 Inhibitors or Inducers", written by Aiqun Li, Karen Yeo, Devin Welty, Haojing Rong, was originally published electronically on the publisher's internet portal (currently SpringerLink) on 02nd November, 2017 without open access.

With the authors' decision to opt for Open Choice the copyright of the article changed on 23rd November, 2017 to (C) The Authors 2017 and the article is forthwith distributed under the terms of the Creative Commons distribution and reproduction in any medium or format, as long as you give appropriate credit to the original author(s) and the source, a link is provided to the Creative Commons license and any changes made are indicated.

The original article has been updated.

Open Access This article is distributed under the terms of the Creative Commons Attribution-NonCommercial 4.0 International License (http://creativecommons.org/licenses/by-nc/4.0/), which permits any noncommercial use, distribution, and reproduction in any medium, provided you give appropriate credit to the original author(s) and the source, provide a link to the Creative Commons license, and indicate if changes were made.

The original article can be found online at https://doi.org/10.1007/ s40272-017-0270-0.

Haojing Rong

hrong@shire.com

1 Drug Metabolism and Pharmacokinetics, Shire, 300 Shire

Way, Lexington, MA 02421, USA

2 Certara Ltd, Sheffield, UK 